\title{
ANALISIS PERAN PEKERJA SOSIAL DALAM PENANGANAN ANAK KORBAN KEKERASAN SEKSUAL DI KOTA BENGKULU
}

\author{
Rosi L. Vini Siregar ${ }^{1)}$, Desy Afrita ${ }^{2)}$ \\ Fakultas Ilmu Sosial dan Ilmu Politik Universitas Bengkulu \\ rosi_siregar@unib.ac.id ${ }^{1}$,dafrita@unib.ac.id ${ }^{2}$
}

\begin{abstract}
ABSTRAK
Kekerasan seksual yang dialami anak dapat berdampak pada kondisi fisik, psikis dan sosial anak yang berpengaruh bagi tumbuh kembang anak di masa mendatang. Atas dasar itu, penanganan anak korban kekerasan seksual memerlukan peran berbagai pihak, termasuk pekerja sosial. Pekerja sosial anak bertujuan untuk memberikan upaya pertolongan, rehabilitasi, dan perlindungan terhadap hakhak anak. Tujuan penelitian ini berupaya mendeskripsikan peran dan hambatan dalam menangani anak korban kekerasan seksual di Kota Bengkulu. Penelitian ini menggunakan pedekatan kualitatif deskriptif, dengan jumlah informan 5 orang. Pengumpulan data dilakukan melalui wawancara, observasi dan studi dokumentasi. Hasil penelitian menunjukkan bahwa peran pekerja sosial dalam menangani anak korban kekerasan seksual dapat berupa fasilitator, broker, inisiator, pelindung, dan advokasi. Adapun faktor penghambat dalam melaksanakan peran ada lima: (a) Hambatan dalam pendanaan (b) kurangnya sarana dan prasarana terkait Perlindungan, (c) Pusat layanan kesejahteraan sosial yang belum tersedia (d) kurangnya SDM yang profesional dalam menangani permasalahan anak, (e) Terbatasnya jejaring menyulitkan pekerja sosial untuk merujuk korban kekerasan seksual anak ke psikolog klinis.
\end{abstract}

Kata Kunci: Peran, Pekerja Sosial, Anak Korban Kekerasan Seksual

\begin{abstract}
Sexual violence experienced by children can have an impact on the physical, psychological and social conditions of children that affect the growth and development of children in the future. On that basis, handling child victims of sexual violence requires the role of various parties, including social workers. Child social workers aim to provide assistance, rehabilitation, and protection of children's rights. The purpose of this study seeks to describe the roles and obstacles in dealing with child victims of sexual violence in Bengkulu City. This study uses a descriptive qualitative approach, with 5 informants using interview, observation and documentation studies. The results showed that the role of social workers in dealing with child victims of sexual violence could be in the form of facilitator, broker, initiator, protector, and advocate. There are five inhibiting factors in carrying out the role: (a) Barriers in funding (b) lack of facilities and infrastructure related to protection, (c) social welfare service centers that are not yet available (d) lack of professional human resources in dealing with children's problems, (e) Limited networks make it difficult for social workers to refer victims of child sexual abuse to clinical psychologists.
\end{abstract}

Keywords: Role, Social Worker, Child Victim of Sexual Violence

\section{PENDAHULUAN}

Kekerasan seksual anak di Indonesia saat ini tercatat sebagai kasus kekerasan anak yang tertinggi. Data yang diperoleh dari Sistem Informasi Online Perlindungan Perempuan dan Anak pada 1 Januari hingga 19 Juni 2020, jumlah kasus kekerasan anak berjumlah 3.087 kasus, diantaranya 852 kasus kekerasan fisik, 768 kasus kekerasan psikis, dan 1.848 kasus kekerasan seksual (kemenpppa.go.id). Jumlah kekerasan seksual anak begitu tinggi setiap tahun, 
menunjukkan posisi anak begitu rentan sebagai korban. Anak sebagai kelompok rentan, menyebabkan kasus kekerasan seksual terhadap anak tidak terlihat dan nyaris tidak terdengar. (Suyanto, 2019)

Provinsi Bengkulu sendiri, merupakan wilayah Sumatera dengan jumlah kekerasan seksual pada anak yang tergolong tinggi. Berdasarkan informasi dari supervisor satuan bhakti pekerja sosial Dinas Sosial Provinsi Bengkulu, korban kekerasan seksual di kota Bengkulu dapat terjadi kepada anak perempuan maupun laki-laki. Pelaku kekerasan seksual pada anak tidak hanya datang dari orang dewasa terdekat, bahkan sering terjadi pada teman sebaya anak yang melakukan kekerasan seksual.

Tabel 1.1

Jumlah Kekerasan Seksual Anak di Bengkulu

\begin{tabular}{|c|c|}
\hline Tahun & $\begin{array}{c}\text { Jumlah Anak Yang Mengalami } \\
\text { Kekerasan Seksual }\end{array}$ \\
\hline 2016 & 109 \\
\hline 2017 & 120 \\
\hline 2018 & 172 \\
\hline 2019 & 147 \\
\hline 2020 & 121 \\
\hline
\end{tabular}

Sumber : Satuan Bhakti Pekerja Sosial Provinsi Bengkulu

Berdasarkan tabel di atas menunjukkan jumlah anak yang mengalami kekerasan seksual di Kota Bengkulu meningkat. Pekerja sosial telah melakukan penanganan terhadap anak korban dengan memegang prinsip kepentingan yang terbaik bagi anak. Masalah kekerasan seksual anak memerlukan penanganan yang tepat bagi tumbuh kembang dan keberlangsungan kehidupan anak.

Anak yang merupakan kelompok lemah dan masih bergantung pada orang dewasa, seringkali dimanfaatkan melalui tipu daya maupun ancaman oleh orang dewasa yang mengakibatkan anak tidak berani mengadukan kekerasan seksual yang terjadi padanya. Hal tersebut mengakibatkan kejahatan yang dilakukan sulit untuk dihindari. Keseluruhan kasus kerasan seksual kepada anak terungkap setelah kejadian, banyak di antaranya berakibat fatal (Gultom, 2013).

Salah satu kasus kekerasan seksual anak di Kota Bengkulu adalah kasus pemerkosaan bergilir oleh pemuda dan juga pembunuhan yang terjadi pada anak berusia 14 tahun yang bernama Yuyun. Pelaku tindak kekerasan seksual terhadap Yuyun berjumlah 14 orang dan diantara pelaku tersebut merupakan usia kategori Anak dengan usia dibawah 18 tahun. Peristiwa tersebut tentu merupakan sebagian kecil dari kasus anak yang mengalami kekerasan di kota Bengkulu, dimana semua kasus ini akan membekas pada anak, dan mempengaruhi tumbuh kembang anak. (Hermaini, 2018).

Dampak negatif kekerasan seksual kepada anak bukan hanya berdampak bagi diri anak saja, melainkan berdampak pada lingkungan dan masyarakat. Pelanggaran norma dan hukum yang dilakukan pelaku, mengakibatkan anak terluka baik secara fisik maupun psikologis. Pada setiap anak yang mengadukan kasus kekerasan seksual yang terjadi kepadanya, masih ada korban-korban lain di 
belakangnya yang tidak melaporkan dengan berbagai alasan. Anak korban kekeraasan seksual baik laki-laki maupun perempuan harus mendapatkan penanganan khusus dari pihak-pihak yang memiliki kompetensi dan memiliki keahlian di bidangnya.

Penelitian yang dilakukan oleh Sakalasastra (2012) untuk mengidentifikasi dampak psikososial pada anak jalanan korban pelecehan seksual menunjukan kecenderungan emosi negatif seperti perasaan benci dan menyimpan dendam, keinginan untuk hidup bebas, penilaian negatif pada diri sendiri dan kehidupan, perilaku seksual yang tidak wajar, penggunaan obat-obatan terlarang dan konsumsi alkohol, serta relasi yang buruk dengan keluarga atau lingkungan sekitarnya. Selain itu, dampak anak yang menjadi korban kekerasan seksual akan mengalami depresi, pendiam, ketakutan untuk keluar rumah, murung, dan tidak banyak bicara (Al haq, 2015).

Menurut UU No. 35 Tahun 2014, anak adalah seseorang yang belum berusia 18 tahun, termasuk anak yang masih dalam kandungan. Perlindungan terhadap anak merupakan serangkaian tujuan untuk menjamin pemenuhan hak-hak anak agar dapat hidup, tumbuh, berkembang, dan berpartisipasi secara optimal sesuai dengan harkat dan martabat kemanusiaan, serta mendapat perlindungan dari kekerasan dan diskriminasi, demi terwujudnya anak Indonesia yang berkualitas, berakhlak mulia, dan sejahtera (UU No.35 Tahun 2014).

Kekerasan seksual terhadap anak adalah tindak pidana dimana pelaku melakukan perbuatan seksual atau mengeksploitasi anak di bawah umur untuk mendapatkan kepuasan seksual berupa menyentuh, mencium alat kelamin anak, perbuatan seksual atau pemerkosaan anak, menampilkan media/benda porno yang memperlihatkan alat kelamin anak, dan sebagainya (Lyness dalam Noviana, 2015).

Adapun efek kekerasan seksual pada anak antara lain: Pertama efek fisik, anak mengalami hambatan pertumbuhan otak dan kerusakan organ dalam, peningkatan resiko penyakit yang berhubungan dengan stres, penurunan nafsu makan, ketidaknyamanan pada alat kelamin, risiko penyakit menular seksual, cedera pada alat kelamin, pendarahan vagina atau dubur, dan kehamilan yang tidak diinginkan. Kedua, efek psikologis trauma pada anak menyebabkan depresi, fobia, mimpi buruk dan ketidakpercayaan terhadap orang lain untuk waktu yang lama. (Sulistyaningsih dalam Kurniawan, 2019). Menurut Brown dalam Rini (2020), 79\% subjek yang mengalami kekerasan seksual dan fisik pada anak juga memiliki keinginan bunuh diri atau melakukan percobaan bunuh diri.

Anak-anak yang menjadi korban kekerasan seksual dan trauma, akan cenderung melakukan hal yang sama kepada orang lain saat dewasa nanti. Hal ini seperti siklus yang terus berlanjut, dan tugas kita dalam menangani kasus-kasus ini adalah mencari cara agar anak yang menjadi korban bisa pulih dari trauma dan memutus siklus tersebut (Judith dalam Octaviana, 2019)

Salah satu peran terpenting dalam menangani anak korban kekerasan seksual adalah peran pekerja sosial. Kekerasan seksual yang diderita oleh anak dapat mempengaruhi tumbuh kembang anak dan mempengaruhi masa depan anak di masa yang akan datang, sehingga diperlukan penanganan khusus untuk mengembalikan fungsi sosial anak. 
Pekerja sosial merupakan seseorang yang memiliki pengetahuan, keterampilan dan nilai praktik pekerjaan sosial serta telah mendapatkan sertifikat kompetensi (UU RI No.14 tahun 2019). Pekerja sosial diharapkan dapat memberikan pelayanan sosial dan rehabilitasi sosial kepada anak yang menjadi korban kekerasan seksual. Masyarakat juga harus memahami bahwa pekerja sosial anak berjuang untuk melindungi hak-hak anak sesuai dengan amanat hukum dan mereka juga memperjuangkan kesejahteraan anak.

Peran pekerja sosial memiliki dampak positif pada anak korban kekerasan seksual. Dengan adanya peran dari pekerja sosial, memudahkan terpenuhinya hak anak untuk mendapatkan akses pada pelayanan sosial. Selain itu, pekerja sosial juga mampu menciptakan suasana yang kondusif bagi anak yang mengalami kekerasan seksual selama proses persidangan, serta memberikan pendampingan dan konsultasi sosial untuk membantu proses rehabilitasi anak.

Peran pekerja sosial dalam menangani permasalahan yang dihadapi dapat bervariasi tergantung pada lingkup permasalahan yang dihadapi. Peran pekerja sosial antara lain : 1) Peranan sebagai perantara (broker roles), 2) Peranan sebagai pemungkin (enabler role), 3) Peranan sebagai penghubung (mediator role), 4) Peranan sebagai advokasi (advocator role), 5) Peranan sebagai perunding (conferee role), 6) Peranan sebagai pelindung (guardian role), 7) Peranan sebagai fasilitasi (facilitator role), 8) Peranan sebagai inisiator (inisiator role), dan 9) Peranan sebagai negosiator (negotiator role) (Wibhawa, 2015).

Pekerja sosial dalam proses pemberian pertolongan dan pelayanan, dituntut untuk menampilkan peran secara profesional. Keberhasilan penanganan anak korban kekerasan seksual tidak luput dari peran dari seorang pekerja sosial perlindungan anak. Untuk itu, perlu dilakukan kajian terhadap peran pekerja sosial dalam menangani anak korban kekerasan seksual di Kota Bengkulu serta hambatan dalam menjalankan peran tersebut.

\section{METODE PENELITIAN}

Pendekatan dalam penelitian ini adalah kualitatif deskriptif. Pengumpulan data dilakukan melalui wawancara, observasi dan studi dokumentasi (Sugiono, 2012). Jumlah Informan dalam penelitian ini adalah 5 orang, terdiri dari pekerja sosial anak dan supervisor pekerja sosial anak. Sumber data penelitian ini terdiri dari data primer dan data sekunder terkait peran pekerja sosial dan hambatan dalam menangani anak korban kekerasan seksual di Kota Bengkulu.Untuk membantu menyempurnakan data yang diperoleh, penelitian ini juga menggunakan literatur (buku, catatan, laporan hasil penelitian sebelumnya). Analisis data dalam penelitian ini dilakukan dengan pengumpulan data, reduksi data, penyajian data, dan penarikan kesimpulan (Sugiono, 2020).

\section{HASIL DAN PEMBAHASAN}

\section{Peran Pekerja Sosial Dalam Menangani Anak Korban Kekerasan Seksual di Kota Bengkulu}

Peran merupakan sesuatu yang harus dilakukan oleh seseorang ketika menduduki suatu jabatan tertentu, serta melaksanakan hak dan kewajiban. Pekerja Sosial dalam penelitian ini merupakan Pekerja Sosial dalam Satuan Bhakti Pekerja 
Sosial Perlindungan Anak (Sakti Peksos PA) yang ditugaskan oleh Kementerian Sosial RI pada setiap kabupaten/kota untuk melaksanakan Program Rehabilitasi Sosial Anak. Pekerja sosial anak di kota Bengkulu berjumlah 5 orang, yang terdiri dari 4 orang pekerja sosial dan 1 orang supervisor. Persyaratan untuk menjadi seorang pekerja sosial anak, ialah memiliki pendidikan Sarjana (S1). Sedangkan untuk Supervisor memiliki pendidikan Magister (S2). Adapun yang menjadi tugas pokok dan fungsi dari pekerja sosial anak ini ialah untuk melakukan upaya perlindungan dan pemenuhan hak-hak anak, termasuk anak yang mengalami kekerasan seksual. Berdasarkan data yang diperoleh menunjukkan beberapa peran pekerja sosial anak di kota Bengkulu dalam menangani anak korban kekerasan seksual, yaitu :

1. Peran Sebagai Fasilitator (Fasilitator Role)

Peran pekerja sosial sebagai fasilitator berkaitan dengan menemukenali permasalahan yang dialami oleh anak. Tujuan dari peran sebagai fasilitator ini ialah memastikan kebutuhan anak terpenuhinya. Dalam melaksanakan peran ini, dibutuhkan keterampilan komunikasi yang baik pada anak. Pekerja sosial di Kota Bengkulu telah melaksanakan peran sebagai fasilitator dan mampu menjalin komunikasi yang baik dengan anak. Sehingga dalam melakukan asessment, pekerja sosial dapat menggali lebih dalam permasalahan yang dialami anak, tanpa membuat anak merasa tertekan. Dengan demikian pekerja sosial akan dapat merumuskan kebutuhan anak melaluiinformasi yang diberikan anak seperti: latar belakang keluarga anak, waktu, tempat dan kronologi kejadian, pelaku, serta mengutarakan pendapat, perasaan dan kebutuhannya, tanpa merasa tertekan.

Peran lainnya yang dilakukan oleh pekerja sosial dalam memfasilitasi anak korban kekerasan seksual antara lain: ketika anak tidak mau berbicara di tempat yang ramai karena takut atau malu,sementara belum ada ruangan khusus untuk pekerja sosial melakukan asesmen kepada anak. Pekerja sosial harus dapat secara aktif dan kreatif untuk mencari solusi, agar dapat memfasilitasi kebutuhan anak akan ruangankhususyang nyaman dan agar privacy anak tetap terjaga. Sebagai contoh dengan berkoordinasi kepada atasan untuk meminjam ruangan khusus untuk berbicara dengan anak. Contoh lain, ketika anak korban rewel dan tidak mau memberikan keterangan. Pekerja sosial juga dapat mengantisipasi dengan mempersiapkan permainan anak dan melakukan pendekatan dengan media permainan, sehingga anak bisa lebih tenang dan dapat dimintai keterangan. Selain itu, bentuk peran pekerja sosial sebagai fasilitator yaitu, ketika anak sebagai korban kekerasan seksual mengalami trauma dan membutuhkan pemeriksaan psikolog anak, maka pekerja sosial akan berupaya memfasilitasi kebutuhan tersebut.

Berdasarkan data yang diperoleh melalui supervisor pekerja sosial anak, pekerja sosial juga memberikan dukungan emosional kepada anak yang mengalami kekerasan seksual dan keluarganya. Dukungan emosional yang diberikan dengan menunjukkan simpati dan kasih sayang kepada anak dan keluarga yang mengalami kasus kekerasan seksual. Selain itu, salah seorang pekerja sosial juga menyatakan pernah mengeluarkan dana pribadi guna membantu anak korban dan keluarga yang tidak memiliki dana untuk bantuan transportasi mereka. 


\section{Peran Sebagai Perantara (Broker Role)}

Peran pekerja sosial sebagai perantara, diartikan sebagai upaya yang dilakukan oleh pekerja sosial dalam membantu klien untuk mendapatkan pelayanan sosial. Berdasarkan hasil penelitian yang dilakukan, keseluruhan informan telah membentuk jejaring kerjasama semaksimal mungkin dengan tujuan agar anak korban kekerasan seksual dapat mendapatkan pelayanan sosial melalui instansi maupun lembaga yang memiliki sumber-sumber yang berhubungan dengan kebutuhan-kebutuhannya.

Kerjasama yang dilakukan antara lain dengan dinas sosial, lembaga, kepolisian, psikolog, Dinas Pemberdayaan Perempuan Perlindungan Anak Pengendalian Penduduk dan Keluarga Berencana (DP3AP2KB), lembaga bantuan hukum,dan sebagainya. Meskipun dalam praktek di lapangan, kerjasama tersebut tidak jarang dilakukan secara informal, dengan bermodalkan relasi saja. Hal ini karena belum ada MoU yang jelas mengenai pelayanan sosial bagi anak korban kekerasan seksual.

Masalah yang biasa dialami oleh anak korban kekerasan seksual yang berkaitan dengan peran pekerja sosial sebagai perantara antara lain: pada saat anak korban mengalami trauma, dimana penanganan kondisi stress pada anak tidak dapat diatasi hanya dengan metode terapi trauma healing yang dikuasai oleh pekerja sosial. Dalam hal ini, peran pekerja sosial sebagai perantara anak yang membutuhkan pengobatan maupun terapi kepadapsikiater/psikolog anak. untuk dilakukan pemeriksaan lanjutan.

Kondisi lain yang berkaitan dengan penanganan anak korban kekerasan seksual dan peran yang dilakukan pekerja sosial sebagai perantara ialah apabila kondisi anak mengalami luka fisik dan memerlukan perawatan, sementara anak tidak memiliki jaminan kesehatan, maka pekerja sosial berupaya untuk mencari solusi dengan berkoordinasi dengan dinas sosial dan dinas kesehatan atau pihak rumah sakit agar anak mendapatkan pelayanan kesehatan.

Selain itu, pekerja sosial juga membantu menghubungkan anak korban kekerasan seksual dengan pusat bantuan hukum, sehingga anak korban yang berasal dari keluarga tidak mampu, namun membutuhkan pendampingan dari pengacara dapat memperoleh bantuan hukum gratis.

Bagi anak korban kekerasan seksual yang keluarganya tidakmampu memenuhi kebutuhan nutrisi anak, pekerja sosial juga menjadi menghubungkan anak dan keluarga kepada Dinas sosial untuk dilakukan pendataan agar diupayakan untuk mendapatkan bantuan bagi Anak Berhadapan Dengan Hukum pada Program Kesejahteran Sosial Anak (PKSA) Kementerian Sosial.

Peran pekerja sosial sebagai perantara kepada layanan sosial, bertujuan untuk memastikan bahwa permasalahan anak ditangani oleh orang/pihak yang lebih ahli dalam menangani permasalahan yang dialami anak. Karena dalam proses rehabilitasi anak korban, pekerja sosial memiliki keterbatasan-keterbatasan. Biasanya anak korban kekerasan seksual juga memerlukan rehabilitasi fisik dan medis. Oleh sebab itu untuk rehabilitasi fisik dan medis biasanya dilakukan oleh tenaga kesehatan, sedangkan upaya untuk rehabilitasi psikis anak dilakukan oleh psikolog anak atau psikiater, sedangkan rehabilitasi sosial anakdilakukan oleh pekerja sosial.Hal ini dalam keilmuan kesejahteraan sosial diistilahkan sebagai 
referal. Karena dalamproses rehabilitasi anak korban, pekerja sosial memiliki keterbatasan-keterbatasan. Itulah sebabnya dilakukan referal/rujukan kepada rekan sejawat, guna memastikan permasalahan anak ditangani oleh pihak yang ahli di bidangnya.

Peran Pekerja sosial sebagai perantara dilaksanakan sesuai dengan kebutuhan anak yang mengalami kekerasan seksual karena dampak yang dialami setiap anak berbeda-beda. Berdasarkan data yang diperoleh, seluruh pekerja sosial menyatakan bahwa peran pekerja sosial sebagai perantara ini dilakukan lebih dari 3 kali dalam setiap kasus.

\section{Peran Pekerja Sosial Sebagai Inisiator (Initiator Role)}

Pekerja sosial sebagai inisiator memberikan perhatian pada masalah atau hal-hal yang memiliki potensi untuk menjadi masalah, dalam hal ini masalah anak korban kekerasan seksual. Peran yang telah dilakukan pekerja sosial di Kota Bengkulu bertujuan untuk menyampaikan informasi dan menyadarkan seluruh masyarakat, lembaga, maupun institusi mengenai isu sosial anak korban kekerasan seksual, kondisi dan kebutuhannya. Berdasarkan data yang didapatkan melalui wawancara kepada supervisor pekerja sosial dan salah seorang staff dinas sosial kota Bengkulu, kegiatan yaang dilakukan pekerja sosial dalam melaksanakan peran sebagi inisiator antara lain:

a. Melakukan kegiatan peksos goes to school, sebagai salah satu upaya pencegahan terjadinya kasus kekerasan di sekolah. Kunjungan dilakukan pada sekolah tertentu, dan materi yang diberikan terkait kekerasan terhadap anak yang terjadi di sekolah. Dalam kegiatan ini, pekerja sosial mengajak anak-anak untuk memahami dan peduli dengan permasalahan kekerasan, khususnya kekerasan seksual di sekolah. Serta mengajak anak berkomitmen untuk tidak melakukan tindak kekerasan di sekolah. Serta memberikan informasi mengenai layanan apabila anak melihat, mendengar, ataupun mengalami masalah kekerasan khususnya kekerasan seksual.

b. Seluruh pekerja sosial melaksanakan kegiatan Temu Penguatan Anak dan Keluarga, sebagai upaya pencegahan kasus kekerasan di lembaga dan keluarga. Kegiatan ini dilaksanakan di Lembaga Kesejahteraan Sosial Anak. Peserta kegiatan ini terdiri dari anak, pengurus LKSA dan keluarga/wali serta masyarakat di sekitar LKSA. Dalam kegiatan ini pekerja sosial juga menyampaikan modul tentang kekerasan pada anak serta dampaknya, sekaligus mempersiapkan keluarga agar mampu menerima keadaan anak dan juga tidak melakukan diskriminasi terhadap anak.

c. Seluruh pekerja sosial bergantian dalam pembagian tugas untuk mengisi acara pada radio lokal. Pekerja sosial pernah aktif mengisi materi terkait perlindungan anak dan perempuan selama 1 kali dalam seminggu pada program Dunia Perempuan. Materi yang disampaikan pada sesi ini terkait upaya pencegahan kekerasan seksual pada anak, penanganan, informasi layanan, hak-hak anak, pengasuhan anak, serta sesi sharing mengenai kekerasan seksual pada anak dan perempuan. Tujuan pelaksanaan program ini ialah untuk mengedukasi masyarakat, dan mengajak masyarakat untuk lebih peduli terhadap kekerasan pada anak dan perempuan. Selain itu, 
kegiatan ini juga sebagai bentuk himbauan kepada masyarakat untuk tidak memberikan labbeling kepada anak korban kekerasan seksual.

d. Seluruh pekerja sosial mengisi materi pada kegiatan webinar untuk memberikan edukasi terkait isu sosial anak korban kekerasan seksual, dan juga informasi mengenai penanganan dan rehabilitasi sosial korban kekerasan seksual anak. Undangan webinar biasanya datang dari lembaga atau institusi mitra yang sama-sama konsern dalam penanganan anak. Berdasarkan data yang diperoleh masing-masing pekerja sosial setidaknya pernah mengisi materi dalam webinar sebanyak 2 kali.

e. Dari data penelitian, pekerja sosial telah menjalin kerjasama dengan kelurahan-kelurahan dan juga dengan pendamping program keluarga harapan yang ada di Kota Bengkulu. Kerjasama yang dilakukan dalam bentuk formal dan informal. Biasanya pekerja sosial diundang dalam kegiatan PKK untuk memberikan materi kepada ibu-ibu PKK. Salah seorang pekerja sosial menyatakan bahwa pekerja sosial bersedia diundang untuk mengisi materi yang berkaitan dengan kekerasan seksual anak meskipun terkadang tidak mendapatkan surat secara formal.

\section{Peran Pekerja Sosial Sebagai Pelindung (Guardian Role)}

Peran yang telah dilakukan pekerja sosial di Kota Bengkulu adalah sebagai pelindung, yaitu melindungi hak-hak anak dan melindungi anak korban kekerasan seksual dari orang-orang yang beresiko tinggi dalam kehidupan sosialnya. Peran ini dilakukan dengan menggali permasalahan yang terjadi pada diri anak korban, dan berupaya untuk menjauhkan anak dari permasalahan tersebut. Misalnya, pelaku kekerasan seksual pada anak adalah guru sendiri sehingga mengakibatkan anak trauma untuk kembali bersekolah di sekolah tersebut. Maka pekerja sosial berupaya untuk menjauhkan anak dari situasi yang menyebabkan trauma pada anak dengan menyarankan kepada keluarga agar anak dipindahkan dari sekolah tersebut demi kebaikan anak.

Pekerja sosial juga mengupayakan agar anak mendapatkan seluruh hakhaknya dan mengupayakan anak mendapatkan pendampingan hukum untuk membela haknya, serta mendapatkan rehabilitasi oleh lembaga yang berwenang. Berdasarkan data yang didapatkan dari salah seorang pekerja sosial, menyatakan bahwa salah satu contoh bentuk perlindungan bagi hak anak yang pernah dilakukan ialah pada anak korban yang mengalami diskriminasi di sekolah. Anak korban yang mengalami kekerasan seksual di bully di sekolah oleh teman-temannya. Hal yang dilakukan oleh pekerja sosial ialah melakukan diskusi kepada keluarga dan pihak sekolah mengenai dampak bagi anak dan upaya untuk memindahkan anak ke sekolah lainnya guna menghindari penolakan dan diskriminasi oleh lingkungan sekolah dan juga masukan dan saran kepada pihak sekolah untuk menghindari permasalahan yang sama terulang kembali melalui kegiatan sosialisasi dengan tema akhiri kekerasan pada anak. Kepada keluarga anak korban, pekerja sosial juga memberikan pemahaman mengenai pentingnya dukungan keluarga pada anak korban kekerasan seksual.

\section{Peran Pekerja SosialSebagai Advokasi (Advocator Role).}


Peran pekerja sosial ini dilakukan berdasarkan dari kepentingan dari klien/korban kekerasan seksual. Peran yang sudah dilakukan antara lain:

a. Pekerja sosial menjadi teman anak, mendengarkan permasalahan anak dengan baik, dan menjadi tempat anak mengekspresikan segala perasaan dan kebutuhannya.

b. Pekerja sosial melakukan analisis terkait permasalahan sosial anak dan merumuskan kebutuhan-kebutuhan anak

c. Pekerja sosial menjadi juru bicara bagi anak, untuk menyampaikan permasalahan anak serta argumentasi mengenai masalah dan kebutuhan anak agar dapat dipenuhi.

d. Ketika terjadi konflik kepentingan pada saat penyampaian permasalahan anak, maka pekerja sosial yang akan menjadi pembela bagi anak. Misalnya dalam hal penyediaan layanan yang dibutuhkan oleh klien tidak tersedia, maka pekerja sosial berupaya untuk menyediakan pelayanan yang dibutuhkan, meskipun kebujakan yang ada tidak responsif atau memihak kepada anak korban. Pekerja sosial akan selalu mengupayakan bahwa dalam melaksanakan perannya memegang teguh pada prinsip kepentingan yang terbaik bagi anak.

e. Pekerja sosial di kota Bengkulu juga aktif berpartisipasi dalam mengawal kebijakan pemerintah yang berkaitan dengan Anak korban kekerasan seksual di Kota Bengkulu.

\section{Hambatan Dalam Menangani Anak Korban Kekerasan Seksual di Kota Bengkulu}

Pekerja sosial dalam menjalankan peran-perannya tentu mengalami hambatan yang menjadi tantangan tersendiri bagi pekerja sosial dalam mengatasi kendala tersebut. Hambatan yang dihadapi pekerja sosial anak di Bengkulu dalam menangani anak korban kekerasan seksual antara lain :

1. Hambatan dana

a. Komitmen pendanaan yang tidak jelas terkait perlindungan anak menyebabkan pekerja sosial terkadang mengalami kesulitan pada saat mendampingi anak korban untuk melaksanakan proses peradilan. Berdasarkan data yang diperoleh dari seluruh pekerja sosial menyatakan bahwa hambatan dalam komitmen pendanaan, terkait belum jelasnya dana yang dapat di akses oleh pekerja sosial untuk membantu anak korban memperoleh bantuan biaya transportasi selama masa persidangan. Sementara untuk shelter sementara bagi anak korban tidak ada, sehingga tidak ada tempat bagi anak dan keluarga, padahal rumah keluarga korban sangat jauh dan keluarga korban berasal dari keluarga yang tidak mampu. Belum adanya panduan yang jelas mengenai dana yang dapat di akses anak korban kekerasan seksual yang bersifat urgent tidak jarang membuat pekerja sosial mengalami hambatan di lapangan dan berupaya untuk mengupayakan bantuan secara informal melalui stakeholder agar anak dan keluarga mendapatkan bantuan dana untuk mengikuti proses persidangan. 
2. Anggaran daerah belum berpihak pada masalah anak korban kekerasan seksual. Permasalahan anak korban kekerasan seksual terkesan terpinggirkan dan tidak dianggap penting. Data yang diperoleh menunjukkan bahwa kasus kekersan seksual pada anak masih belum mendapatkan perhatian khusus dari pemerintah daerah terkait sarana prasarana bagi anak korban kekerasan seksual dan penganggaran khusus belum terlaksana.

3. Hambatan sarana prasarana

a. Kurangnya dukungan sarana dan prasarana bagi Pekerja Sosial di Dinas Sosial, seperti tidak tersedianya ruangan khusus pekerja sosial untuk melakukan assessment sehingga pekerja sosial kesulitan dalam menyediakan ruangan yang kondusif untuk melakukan asesmen pada anak.

b. Perlindungan anak korban. Rumah Perlindungan Sosial Anak (RPSA), satu-satunya tempat yang dapat digunakan sebagai rumah aman bagi anak untuk sementara di Bengkulu dalam keadaan vakum, sehingga tidak ada tempat khusus untuk merujuk klien sementara proses pemeriksaan berlangsung.

4. Hambatan pusat layanan

Belum adanya Pusat layanan Kesejahteraan Sosial di Bengkulu bagi klien yang membutuhkan terapi ataupun rehabilitasi. Sehingga harus dirujuk ke balai di provinsi lain yang letaknya jauh dari Bengkulu.

5. Hambatan Sumber Daya Manusia

Sumber Daya Manusia yang terlatih dan professional dalam menangani permasalaahan anak sangat minim. Jumlah satuan bakti pekerja sosial hanya 5 orang, sementara jumlah kasus anak meningkat dan membutuhkan waktu yang lama dalam proses penanganannya. Pembangunan fisik rumah aman bagi anak sudah ada, tetapi tidak ada staff yang profesional yang dipekerjakan untuk mengaktifkan rumah aman tersebut.

6. Hambatan pada jejaring

Jejaring yang terbatas menyebabkan pekerja sosial kesulitan dalam merujuk anak korban kekerasan seksual kepada psikolog klinis. Pekerja sosial hanya mampu merujuk anak ke psikolog umum, karena untuk merujuk anak kepada psikolog klinis berbayar, sementara Dinas Sosial belum memiliki MoU dengan RS Jiwa yang memiliki tenaga Psikolog Klinis.

\section{SIMPULAN}

Pekerja sosial telah melaksanakan peran dalam menangani korban kekerasan seksual anak di Kota Bengkulu dengan tetap memegang teguh prinsip kepentingan yang terbaik bagi anak. Peran-peran yang telah dilakukan antara lain: peran sebagai fasilitator, broker (penghubung), mediator, pembela, pelindung dan pendidik.

Upaya pekerja sosial anak di Kota Bengkulu dalam menangani anak yang menjadi korban kekerasan seksual meliputi: tindakan preventif, kuratif dan rehabilitatif. Pekerja Sosial juga berupaya berupaya semaksimal mungkin untuk membangun jejaring kerja dengan pemangku kepentingan terkait, meskipun 
hambatan yang terjadi di lapangan membutuhkan tantangan tersendiri bagi pekerja sosial dalam mengatasinya karena tindakan yang dibutuhkan seringkali belum memiliki MoU yang jelas. Namun demikian, pekerja sosial tetap profesional dalam bekerja meskipun dengan sumber daya yang minim.

Permasalahan tempat perlindungan anak korban kekerasan seksual, dan akses biaya operasional bagi penanganan kasus anak korban kekerasan seksual mestinya menjadi perhatian bagi setiap pemangku kebijakan. Permasalaan anak berhadapan dengan hukum di Kota Bengkulu meningkat setiap tahunnya. Untuk itu diperlukan peran dan komitmen dari seluruh stakeholder untuk bersinergi dalam mengatasi permasalahan yang dihadapi oleh anak korban kekerasan seksual di Kota Bengkulu.

\section{REFERENSI}

Al haq, dkk.(2015). Kekerasan Seksual Pada Anak Di Indonesia. Prosiding Penelitian dan Pengabdian kepada Masyarakat. Vol. 2 (1). Hal. 31-36

Gultom, Maidin. (2013). Perlindungan Hukum terhadap Anak Dalam Sistem Peradilan Pidana Anak Di Indonesia. Bandung: Rafika Aditama

Hermaini. (2018). Lindungi Anak Dari Korban dan Pelaku Pelecehan Seksual. Jurnal Ilmiah Kesejahteraan Sosial. Quantum, Vol. XIV(26).Hal.121-133

Huraerah, A. (2018). Kekerasan terhadap anak: Fenomena masalah sosial kritis di Indonesia. Bandung: Nuansa.

Kemenpppa. (2020). Angka kekerasan Terhadap Anak Tinggi Di Masa Pandemi, KemenPPPA Sosialisasikan Protokol Perlindungan Anak. Diakses dari https://www.kemenpppa.go.id/index.php/page/read/29/2738/angka-

kekerasan-terhadap-anak-tinggi-di-masa-pandemi-kemen-pppasosialisasikan-protokol-perlindungananak\%20diakses\%20pada\%2024\%20Juni\%202020 (30 Juni 2020)

Kurniawan, dkk. (2019). Peran Pekerja Sosial Dalam Menangani Anak Korban Kekerasan Seksual.Prosiding Penelitian Dan Pengabdian Kepada Masyarakat. 1(1). Hal.21-32

Noviana, Ivo. (2015). Kekerasan Seksual Terhadap Anak: Dampak Dan Penanganannya. Jurnal Sosio Informa, Vol. 1 (1). Hal. 13-28

Octaviana, Nur (2019) Child Sexual Abuse in Indonesia: History and Challenge in Legal Perspective. Indonesian Journal Of Criminal Law Studies. Vol. 4 (1). Hal 81-89

Republik Indonesia. (2014). Undang Undang RI No 35 Tahun 2014 Tentang Perlindungan Anak. Jakarta : Kementerian Sosial

Republik Indonesia. (2019). Undang-undang RI No 14 tahun 2019 Tentang Pekerja Sosial. Jakarta : Kementerian Sosial

Rini. (2020). Dampak Psikologis Jangka Panjang Kekerasan Seksual Anak (Komparasi Faktor: Pelaku, Tipe, Cara, Keterbukaan Dan Dukungan Sosial). Jurnal IKRA-ITH Humaniora, Vol. 4 (3), November 2020. Hal. 157-167

Sakalasastra, Pandu. (2012) Dampak Psikososial Pada Anak Jalanan Korban Pelecehan Seksual Yang Tinggal di Liponsos Anak Surabaya. Jurnal Psikologi Kepribadian dan Sosial. Vol. 1 (2), Agustus 2012 . Hal. 99-104 
Suyanto, Bagong. (2019). Sosiologi Anak. Jakarta :Prenadamedia Group Sugiyono. (2020). Metode Penelitian Kualitatif : Untuk Penelitian yang bersifat eksploratif, enterpretif, interaktif dan konstruktif. Bandung: Alfabeta

---------. (2012). Metode Penelitian Kuantitatif, Kualitatif Dan R\&D. Bandung : Alfabeta

Sulistyaningsih, E., \& Faturochman. (2002). Dampak Sosial Psikologis Perkosaan. Buletin Psikologi Buletin Psikologi, Vol 10 (1). Hal. 9-23

Wibhawa, Budhi. (2015). Pengantar Kesejahteraan Sosial. Bandung : Unpad Press

Yoga, Tateki. (2017). Dampak Kekerasan Seksual Di Ranah Domestik Terhadap Keberlangsungan Hidup Anak. Media Informasi Penelitian Kesejahteraan Sosial, Vol. 41(1), April 2017. Hal.77-92 